\title{
Do Indonesian EFL Textbooks Represent Equality for Men and Women?
}

\author{
Arcci Tusita ${ }^{1}$, Ive Emaliana ${ }^{2}$ \\ \{arcci_tusita@ub.ac.id'1 ${ }^{1}$ ive@ub.ac.id² \\ Universitas Brawijaya, Indonesia ${ }^{1,2}$
}

\begin{abstract}
The present study attempts to examine the equal representations of males and females in the EFL textbooks as it is being suggested by Indonesian Education and Culture Ministry Bill Number 81 A Year 2013 that "kurikulum diarahkan kepada pengembangan sikap dan perilaku yang berkeadilan dengan memperhatikan kesetaraan gender" (the curriculum should meet be directed into the manner development and fair attitude with the emphasis on gender equality). Researchers attempt to achieve this by examining three English textbooks. This study uses descriptive method in picturing the content of textbook and explaining the gender equality representation of textbook. The analysis is based on five experts' checklist namely Cohen and Manion (1992), Dominiguez (1992), Ching (2014), Porreca (1984) and Stockdale (2006) for the language items dimensions. The data are collected by identifying the content of textbook with criteria dimensions on the gender representation textbook evaluation checklist. The findings from the evaluation indicate that gender representation in the textbooks are unequal that might due to the culture and country development level which enriched the discussions.
\end{abstract}

Keywords: Gender Equality, Gender Representation, EFL Textbooks.

\section{Introduction}

The importance of awareness about gender equality in Indonesia's development is regulated through various government regulations as the basis for its implementation. The convention on the elimination of all forms of discrimination against women (CEDAW) has been ratified by the Indonesian government through Law Number 7/1984 in the last thirty-five years ago. Gender mainstreaming in Indonesia's development has been launched since 2000 through Presidential Instruction Number 9 which incorporates gender perspective from the planning, preparation, implementation, monitoring, to evaluation and utilization of its results in national development [1].

In addition, in 2006, the Ministry of Women Empowerment and Child Protection (MoWECP) prepared a draft of Government Regulation on Gender Mainstreaming from a philosophical aspect to strengthen the legal framework based on Pancasila as the philosophy of the State, especially the second principle of Pancasila "just and civilized humanity" and The fifth principle "social justice for all Indonesian people". Thus, the document of global agreement on the Sustainable Development Goals (SDG) was made. The document that aims to achieve gender equality and empower all women and girls to realize gender equality and justice, is carried out through the fulfilment of five targets, which include (1) ending all forms of discrimination, (2) eliminating all forms of violence, (3) eliminating all harmful practices, (4) 
realizing and valuing services and work and (5) ensuring that all women can participate fully in political, social and economic life.

Therefore, the education curriculum is stipulated through the Ministerial Regulation Number $81 / 2013$ stating that the curriculum is oriented to the development of rightful attitudes and behaviors that pay attention to gender equality. Educational actors, both lecturers and teachers, are provided with learning facilities consisting of material, which is usually bridged by textbooks or other teaching materials. Textbooks are important tools in the education system for several reasons, among others (1) textbooks are developed based on the ideological perspective of groups that have an important role in the social and economic community [2], (2) textbooks introduce students to powers and beliefs in life as embraced by the majority group [3], and (3) textbooks reflect social aspects of the social life [4]. As an artifact of social life, in addition to facilitating learning materials, textbooks that play an important role in education should also have a mission to raise awareness of gender equality, which in the Indonesian context is represented as a dominant patriarchal culture and the construction of femininity and masculinity in gender stereotypes which is communicated, nurtured, and negotiated through various cultural activities. This research is therefore a textbook analysis that seeks to map the extent to which English textbooks accommodate the idea of gender equality.

\section{Literature Review}

\subsection{Textbooks as Gender Responsive Learning Media}

As a part of education system, teachers can be agents of change in gender equality or even exacerbate stereotypical disparities on gender equality in the classroom. So, there is a need for learning material that supports gender equality, such as textbooks. But gender biases in the curriculum [5][6] and learning materials [7][8] are still widely found in developing countries. The results of the analysis of gender equality through photographs, images and text that are biased in gender stereotypes are even stronger. In Indonesia, the results of research on gender analysis in textbooks for schools are found to exhibit gender bias [9]-[11].

Efforts to mainstream gender equality in the curriculum and learning materials in textbooks are manifested through incorporating a gender perspective and a gender-sensitive approach. This can be done by establishing formal institutions whose task is to eliminate gender stereotypes in textbooks and other learning materials [12]. One of the regulations that specify gender equality awareness in the educational sector is the Minister of Education and Culture's Regulation Number $81 \mathrm{~A} / 2013$ which states that the curriculum is directed towards the development of equitable attitudes and behaviors with regard to gender equality. However, even though this regulation has recognized equal rights and positions between women and men, in reality there are often inequalities in their representation in textbooks.

\subsection{Awareness in Gender Equality}

Gender perspective is a perspective that looks at the impact of one's gender attributes to build opportunities, social roles, and their interactions with opposite gender attributes [8], differences caused by social construction are called gender differences [13].

Ching [6] states that textbooks as a knowledge construction tool often contain a hidden curriculum, namely concepts learned by students through cultural norms in society and 
dominant power structures presented in textbooks. Gender insensitivity and inequality occur due to the influence of patriarchal culture which is widespread and rooted in Indonesian society. This culture is accidentally disseminated in the world of education which should uphold gender equality. Based on Law Number 20 article 5 paragraph 1/2003, teaching and learning must pay attention to the issue of gender equality. Thus, the quality teaching textbooks that pay attention to the concept of gender mainstreaming are substantially needed in order to achieve learning objectives with a gender perspective. A book with a gender perspective is a book that is sensitive to gender issues, illustrates equality and justice between men and women and leaves behind false gender stereotypes.

\section{Research Method}

Sources of data, data collection, and data collection techniques were conducted by doing needs analysis quantitatively and descriptively towards four English books that must be used by Middle and High School students, namely 8th grade English books, 10th grade, 11th grade and the 11th grade of Vocational High School English books. The instruments used are as follows.

Table 1. Research Instrument

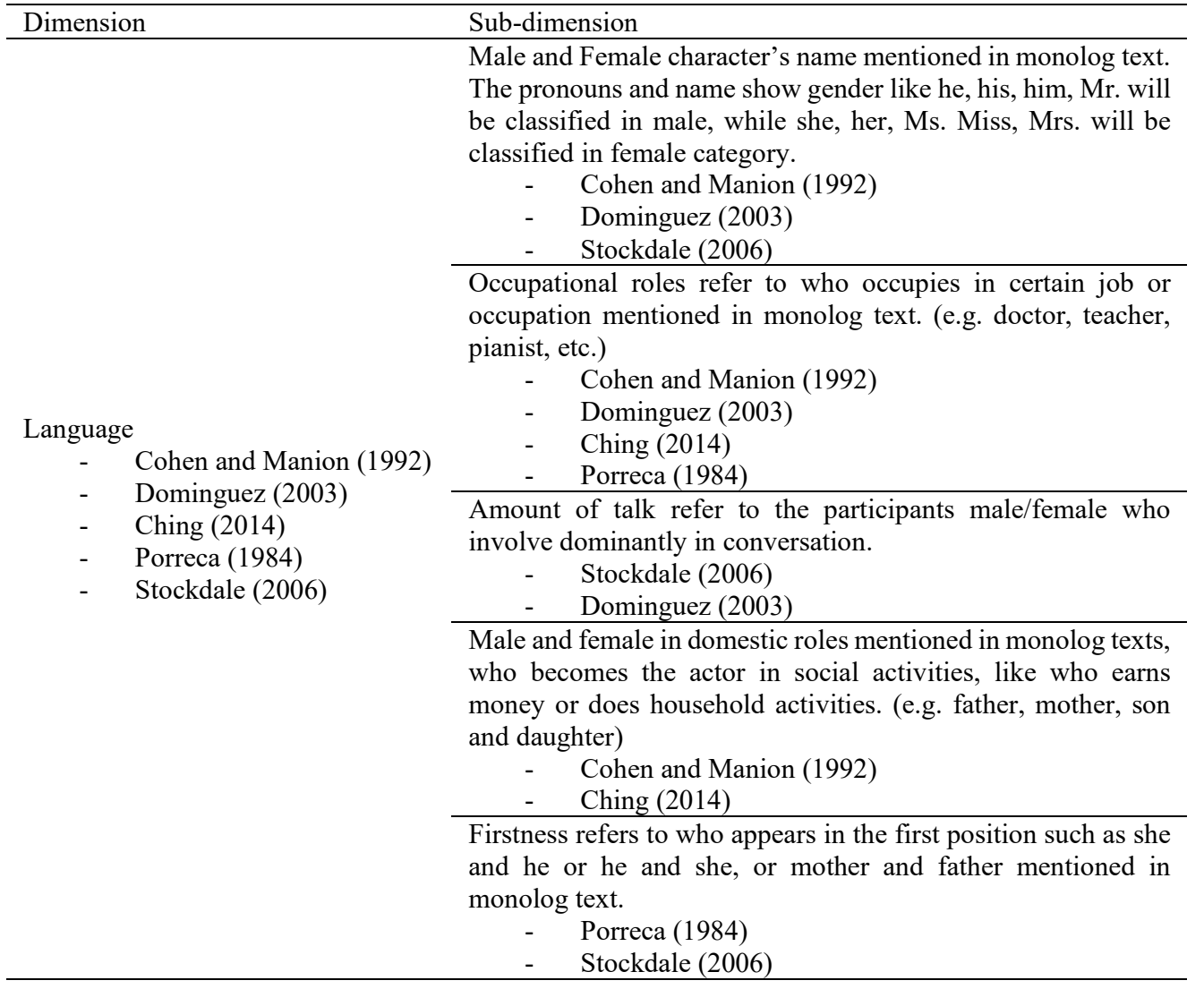


The main instrument of this research is a checklist containing the theories of five experts that can identify aspects of the gender perspective analyzed from the language aspects of the textbook. If the difference in the amount obtained from counting the texts and illustrations from stereotypes of women and men is more than $5 \%$, then it is categorized as a gender bias [14].

\section{Result and Discussion}

There were five sub-dimension that described the criteria of language items in monolog texts. They were male and female characters name mentioned in monolog texts, occupational roles refer to who occupies in a certain job or occupation mentioned in monolog texts, amount of talk refers to participants male and female who involve dominantly in conversation, male and female in domestic roles are mentioned in monolog texts, who become the actor in social activities, firstness refers to who appears in the first position.

\subsection{Male and female characters name}

Most of the reading activities presented in four textbooks use male characters. The number of male and female characters' names mentioned in monolog texts show 1154 for male and 334 for female. As portrayed in the Table 2 the male and female characters' monolog texts in Bahasa Inggris SMP grade 8, SMA grade 10 and 11 and SMK grade 11 showed that $77 \%$ for male $23 \%$ for female. This percentage shows imbalance portion for male and female and promote gender inequality.

Table 2. Male and Female Characters Name

\begin{tabular}{|c|c|c|c|c|c|c|c|}
\hline \multirow[b]{2}{*}{ Dimension } & \multirow[b]{2}{*}{ Sub-dimension } & \multirow[b]{2}{*}{ Book } & \multicolumn{2}{|c|}{ Number } & \multicolumn{3}{|c|}{ Percentage } \\
\hline & & & M & $\mathrm{F}$ & M & $\mathrm{F}$ & $\begin{array}{c}\text { Gender not } \\
\text { specified }\end{array}$ \\
\hline \multirow{5}{*}{$\begin{array}{l}\text { Language items } \\
\text { According to: } \\
\text { - Cohen and } \\
\text { Manion (1992) } \\
\text { - Dominguez } \\
\text { (2003) } \\
\text { - Ching (2014) } \\
\text { - Porreca (1984) } \\
\text { - Stockdale } \\
\text { (2006) }\end{array}$} & \multirow{5}{*}{$\begin{array}{l}\text { Male and Female } \\
\text { character's name } \\
\text { mentioned in } \\
\text { monolog text. The } \\
\text { pronouns and name } \\
\text { show gender like he, } \\
\text { his, him, Mr. will be } \\
\text { classified in male, } \\
\text { while she, her, Ms. } \\
\text { Miss, Mrs. will be } \\
\text { classified in female } \\
\text { category. }\end{array}$} & $\begin{array}{c}\text { English } \\
\text { Textbook for } \\
\text { Grade } 8\end{array}$ & 67 & 24 & $74 \%$ & $26 \%$ & - \\
\hline & & $\begin{array}{c}\text { English } \\
\text { Textbook for } \\
\text { grade } 10 \\
\end{array}$ & 174 & 127 & $57 \%$ & $43 \%$ & - \\
\hline & & $\begin{array}{l}\text { English textbook } \\
\text { for grade } 11\end{array}$ & 150 & 95 & $61 \%$ & $39 \%$ & - \\
\hline & & $\begin{array}{c}\text { English textbook } \\
\text { for SMK grade } \\
11\end{array}$ & 163 & 98 & $62 \%$ & $38 \%$ & - \\
\hline & & Total & 1154 & 344 & $77 \%$ & $23 \%$ & \\
\hline
\end{tabular}




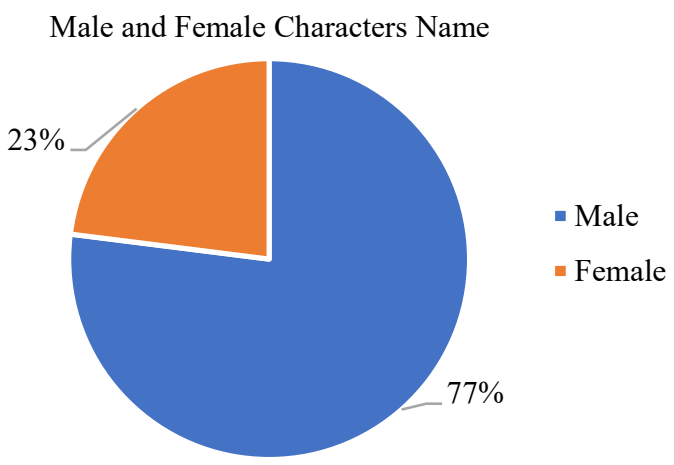

Fig. 1. Percentage of male and female characters name for language items dimension.

Gender bias in terms of male and female names in four middle and high school textbooks comes from the unbalanced appearance of male and female figures in the text of the textbook. There are more texts with male characters, such as stories about the inventor of the plane, biography of B. J. Habibie and others which tell about the male figures. On the other hand, less texts highlight the lives of woman figures. The implication of this problem is that students will be more exposed to the experience of men which of course tell a narrative about masculinity. While in fact, feminine narratives told from female point of views are also important to be explored and understood to create better understanding of gender equality.

\subsection{Occupational Roles}

The textbooks showed occupational roles male is dominant in monolog texts. The number of male and female occupational roles mentioned in monolog texts show 12 or $67 \%$ for male and 7 or $37 \%$ for female, so in the male and female occupational roles of representation of gender equality is imbalance.

Table 3. Occupational Roles

\begin{tabular}{|c|c|c|c|c|c|c|c|}
\hline \multirow[b]{2}{*}{ Dimension } & \multirow[b]{2}{*}{ Sub-dimension } & \multirow[b]{2}{*}{ Book } & \multicolumn{2}{|c|}{ Number } & \multicolumn{3}{|c|}{ Percentage } \\
\hline & & & $\mathrm{M}$ & $\mathrm{F}$ & M & $\mathrm{F}$ & $\begin{array}{l}\text { Gender not } \\
\text { specified }\end{array}$ \\
\hline \multirow{5}{*}{$\begin{array}{l}\text { Language items } \\
\text { According to: } \\
\text { - Cohen and } \\
\text { Manion (1992) } \\
\text { - Dominguez } \\
\text { (2003) } \\
\text { - Ching (2014) } \\
\text { - Porreca (1984) } \\
\text { - Stockdale } \\
\text { (2006) }\end{array}$} & \multirow{5}{*}{$\begin{array}{l}\text { Occupational roles } \\
\text { refer to who } \\
\text { occupies in certain } \\
\text { job or occupation } \\
\text { mentioned in } \\
\text { monolog text. (e.g. } \\
\text { doctor, teacher, } \\
\text { pianist, etc.) }\end{array}$} & $\begin{array}{c}\text { English } \\
\text { Textbook for } \\
\text { Grade } 8 \\
\end{array}$ & 4 & 4 & $50 \%$ & $50 \%$ & T \\
\hline & & $\begin{array}{l}\text { English } \\
\text { Textbook for } \\
\text { grade } 10\end{array}$ & 4 & 1 & $80 \%$ & $20 \%$ & 1 \\
\hline & & $\begin{array}{l}\text { English } \\
\text { textbook for } \\
\text { grade } 11\end{array}$ & 3 & 1 & $75 \%$ & $25 \%$ & \\
\hline & & $\begin{array}{c}\text { English } \\
\text { textbook for } \\
\text { SMK grade } 11\end{array}$ & 5 & 1 & $83 \%$ & $17 \%$ & 1 \\
\hline & & Total & 12 & 7 & $67 \%$ & $37 \%$ & \\
\hline
\end{tabular}




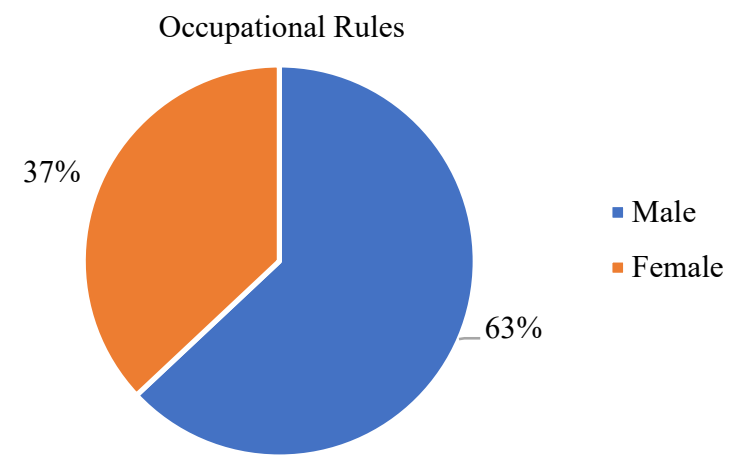

Fig. 2. Percentage of Occupational Roles for Language Items Dimension.

Gender inequality about male and female occupational roles in four English books are not only seen quantitatively, but also qualitatively. Generally, women's jobs are associated with nurturing activities, such as teachers or clerical jobs such as bank teller. This confirms the stereotypes of woman of being meticulous and patient. Meanwhile, the portrayal of men's occupational roles in the four English textbooks are more various, such as athletes, scientists, singers and presidents. Through this various portrayal of jobs, men are indirectly seen as more complex and more capable of building a professional career. Furthermore, the kinds of jobs displayed also confirms the traditional value of masculinity that men are physically strong, logical and have strong sense of leadership.

\subsection{Amount of Talk}

The researchers found as portrayed in the Table 4, the male and female amount of talk in monolog texts in four textbooks showed that $52 \%$ for male and $48 \%$ for female. Thus, in the male and female amount of talk refers to dominantly in the conversation of representation of gender equality is imbalance.

Table 4. Amount of Talk

\begin{tabular}{|c|c|c|c|c|c|c|c|}
\hline \multirow[b]{2}{*}{ Dimension } & \multirow[b]{2}{*}{ Sub-dimension } & \multirow[b]{2}{*}{ Book } & \multicolumn{2}{|c|}{ Number } & \multicolumn{3}{|c|}{ Percentage } \\
\hline & & & M & $\mathrm{F}$ & $\mathrm{M}$ & $\mathrm{F}$ & $\begin{array}{l}\text { Gender not } \\
\text { specified }\end{array}$ \\
\hline \multirow{5}{*}{$\begin{array}{l}\text { Language items } \\
\text { According to: } \\
\text { - Cohen and } \\
\text { Manion (1992) } \\
\text { - Dominguez } \\
\text { (2003) } \\
\text { - Ching (2014) } \\
\text { - Porreca }(1984) \\
\text { - } \text { Stockdale (2006) }\end{array}$} & \multirow{5}{*}{$\begin{array}{l}\text { Amount of talk } \\
\text { refer to the } \\
\text { participants } \\
\text { male/female } \\
\text { who involve } \\
\text { dominantly in } \\
\text { conversation. }\end{array}$} & $\begin{array}{l}\text { English Textbook } \\
\text { for Grade } 8\end{array}$ & 168 & 126 & $57 \%$ & $43 \%$ & - \\
\hline & & $\begin{array}{l}\text { English Textbook } \\
\text { for grade } 10\end{array}$ & 83 & 70 & $54 \%$ & $46 \%$ & - \\
\hline & & $\begin{array}{l}\text { English textbook } \\
\text { for grade } 11\end{array}$ & 50 & 66 & $43 \%$ & $57 \%$ & - \\
\hline & & $\begin{array}{l}\text { English textbook } \\
\text { for SMK grade } 11 \\
\end{array}$ & 85 & 71 & $54 \%$ & $46 \%$ & - \\
\hline & & Total & 386 & 333 & $52 \%$ & $48 \%$ & \\
\hline
\end{tabular}




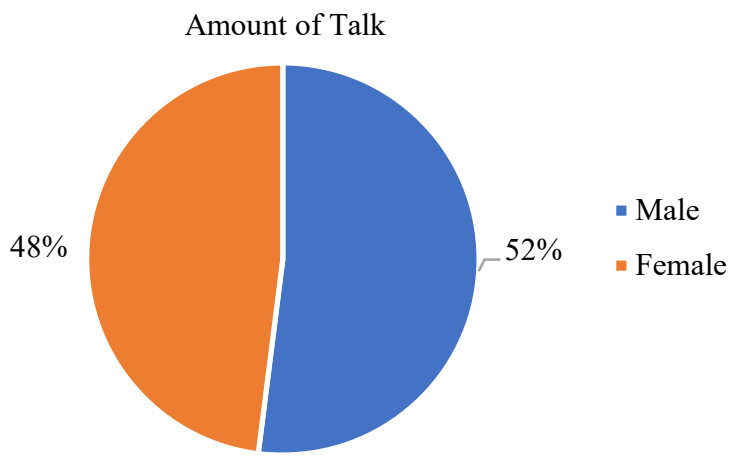

Fig. 3. Percentage of Amount of Talks for language items dimension.

In general, four textbooks for secondary schools show men always actively express their opinion and often depicted as the ones who initiate conversation. Interestingly, one of the data found in English Lesson grade 8 places woman as object. It can be seen as the following quotation.

Male 1: is the man staring at the woman?

Male 2: yes, he is staring at her

In patriarchal society, men are placed as the subjects, while women are the objects who always dependent to men's will. This can be seen from the above excerpt; women are positioned as objects that are seen by men. In fact, the idea that women are objects is the root of not only gender inequality in society, but also violence that occurs to women.

On the other hand, the context of $48 \%$ women's involvement in conversations confirms the stereotype of traditional femininity. The conversations that are dominated by women are those which allow women to carry out their role of nurturing others. There are several examples which confirm this presupposition, such as a woman offers to buy souvenirs before going out of town, or a woman who initiates to buy gifts to a friend. Women's utterances as responses to male speakers are related to a willingness to provides helps and services, such as lending stationary and telling stories.

\subsection{Male and Female in Domestic Roles}

The textbooks showed male are more dominantly involve in domestic roles. The number of male and female domestic roles mentioned in monolog texts show 12 or $67 \%$ for male and 8 or $40 \%$ for female. So, in the male and female occupational roles of representation of gender equality is imbalance.

Table 5. Male and female in Domestic Roles

\begin{tabular}{lllllllll}
\hline & \multicolumn{1}{c}{ Sub-dimension } & Book & M & F & M & F & $\begin{array}{c}\text { Gender not } \\
\text { specified }\end{array}$ \\
\cline { 3 - 8 } $\begin{array}{l}\text { Language items } \\
\text { According to: }\end{array}$ & $\begin{array}{l}\text { Male and female in } \\
\text { domestic roles mentioned } \\
\text { in monolog texts, who }\end{array}$ & $\begin{array}{c}\text { English } \\
\text { Textbook for } \\
\text { Grade 8 }\end{array}$ & 2 & 2 & $50 \%$ & $50 \%$ & - \\
\hline
\end{tabular}




\begin{tabular}{|c|c|c|c|c|c|c|}
\hline \multirow{4}{*}{$\begin{array}{l}\text { - Cohen and } \\
\text { Manion (1992) } \\
\text { - Dominguez } \\
\text { (2003) } \\
\text { - Ching (2014) } \\
\text { - Porreca (1984) } \\
\text { - Stockdale } \\
\text { (2006) }\end{array}$} & \multirow{4}{*}{$\begin{array}{l}\text { becomes the actor in } \\
\text { social activities, like who } \\
\text { earns money or does } \\
\text { household activities. (e.g. } \\
\text { father, mother, son and } \\
\text { daughter }\end{array}$} & $\begin{array}{c}\text { English } \\
\text { Textbook for } \\
\text { grade } 10\end{array}$ & 3 & 1 & $75 \% \quad 25 \%$ & - \\
\hline & & $\begin{array}{l}\text { English textbook } \\
\text { for grade } 11\end{array}$ & 4 & 3 & $57 \% \quad 43 \%$ & - \\
\hline & & $\begin{array}{l}\text { English textbook } \\
\text { for SMK grade } \\
11\end{array}$ & 3 & 2 & $60 \% \quad 40 \%$ & - \\
\hline & & Total & 12 & 8 & $60 \% 40 \%$ & \\
\hline
\end{tabular}

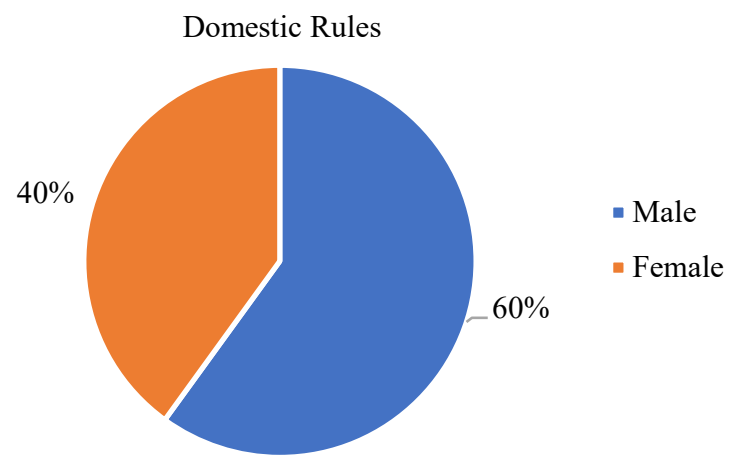

Fig. 4. Percentage of Male-Female Domestic roles for language items dimension.

The division of male-female roles in social life depicted in the four English language textbooks for secondary schools is quantitatively and qualitatively inequal. In the monolog texts, the role of men is very dominant and complex; men involve actively in both professional and community activities. The activities such as neighborhood meetings (pertemuan $R T / R W$ ) is the example of men's participation in community activities.

\subsection{Firstness}

'Firstness' refers to the linguistic feature where one particular gender is often mentioned first. In other words, it deals with two gender-specific nouns or pronouns appeared as a pair, like 'mother and father' or 'he or she' [15]. Firstness implies that the one appearing first could be interpreted as having higher status. The findings revealed the following: males were in the first position most times, while females were in first position in only $35 \%$.

\begin{tabular}{|c|c|c|c|c|c|c|c|}
\hline \multicolumn{8}{|c|}{ Table 6. Firstness } \\
\hline \multirow[b]{2}{*}{ Dimension } & \multirow[b]{2}{*}{ Sub-dimension } & \multirow[b]{2}{*}{ Book } & \multicolumn{2}{|c|}{ Number } & \multicolumn{3}{|c|}{ Percentage } \\
\hline & & & $\mathrm{M}$ & $\mathrm{F}$ & $\mathrm{M}$ & $\mathrm{F}$ & $\begin{array}{l}\text { Gender not } \\
\text { specified }\end{array}$ \\
\hline \multirow{3}{*}{$\begin{array}{l}\text { Language items } \\
\text { According to: } \\
\text { - Cohen and } \\
\text { Manion (1992) } \\
\text { - Dominguez } \\
\text { (2003) } \\
\end{array}$} & \multirow{3}{*}{$\begin{array}{l}\text { Firstness refers to } \\
\text { who appears in the } \\
\text { first position such as } \\
\text { she and he or he and } \\
\text { she, or mother and }\end{array}$} & $\begin{array}{l}\text { English Textbook } \\
\text { for Grade } 8\end{array}$ & 25 & 20 & $56 \%$ & $44 \%$ & - \\
\hline & & $\begin{array}{l}\text { English Textbook } \\
\text { for grade } 10\end{array}$ & 23 & 11 & $68 \%$ & $32 \%$ & - \\
\hline & & $\begin{array}{l}\text { English textbook } \\
\text { for grade } 11\end{array}$ & 8 & 3 & $73 \%$ & $27 \%$ & - \\
\hline
\end{tabular}




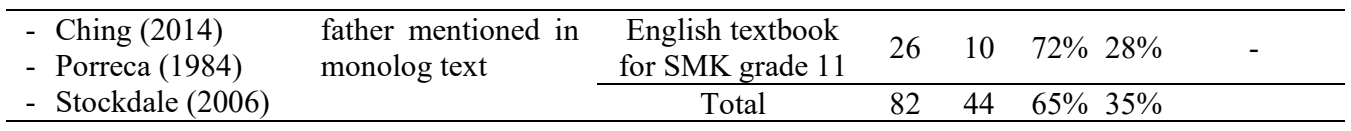

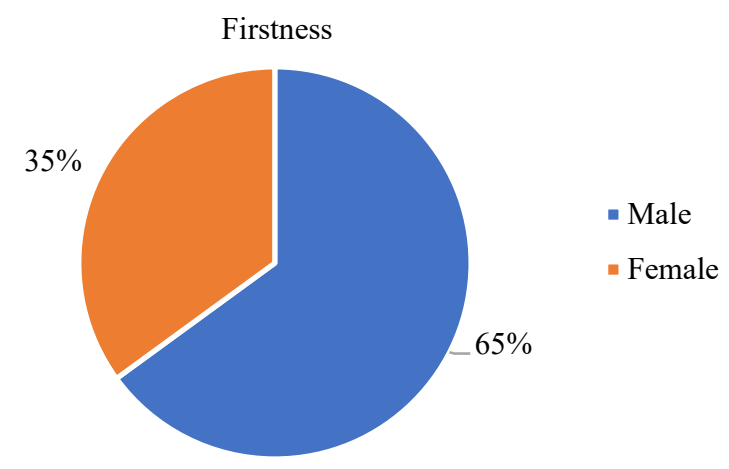

Fig. 5. Percentage of Firstness for language items dimension.

The result represents a common conviction that men are more important than women in almost every society, suggesting that it is necessary to place them first everywhere. These four textbooks reinforce the stereotypical notion of who is regarded as more worthy and important in society. This automatic ordering reinforces the second-place status of women and is one of the ways in which the power status of men is reinforced. This can be an indicator of asymmetrical relations of power [16]; in this instance, the authors are placed in the position of being the possessors and providers of knowledge while the readers are receivers. Because textbooks are seen by students as holding unquestionable truths, they will accept this version of reality. Thus, as the effect of this kind of portrayal, female learners will feel weak and unimportant in comparison to male learners. The ideology of masculine superiority will also affect female learners' self-esteem.

Accordingly, under pedagogical concern, these results are compatible with those reported by Al-qatawneh \& Al-rawashdeh [8] that women is underrepresentation in EFL textbooks, gender stereotypes are an issue worthy of the authors' attentions. Besides, gender nonrepresentation issues, when females do not represent as often as men in the textbooks in schools, suggests that women's achievement are not significant to be pointed out [16]. The textbook authors and curriculum developers who were involved in developing and preparing the English language lesson curriculum in high school's process may involve equal gender representations notably for its written discourse in passages in the textbooks. Given that EFL textbooks as educational materials are amongst the most pivotal socialization representatives, the representation of two genders should be balanced in textbooks, on the contrary, if gender imbalance are not proper in textbooks used in schools, in the future time, it brings detrimental society by causing too many social problems [13]. Even though it probably not be right to always represent the same ratios of the two genders in different circumstances, textbook authors should consider equal appearances in the school textbooks. In developing countries, social reconstruction might commence in the classroom where textbooks representing both females and males more equal, for textbooks have a pivotal aspect in students' education [17]. To respond biases coming from the society into classroom, textbooks with comprehensive contents might help a lot. Thus, the grand design for coping with gender differentiation and 
underrepresentation issues, as they are revealed in school, textbooks contents, should be a prime concern for school textbooks' authors, supported by the Indonesian ministry of Education.

\section{Conclusion}

Women in the written and visual text of the textbooks studied are marginalized, subordinated, stereotyped and given second-place status to that of male. The most common form of marginalization was under-representation, while stereotyping largely happened through discourse marginalization. As textbooks are foregrounded as the official and authorized texts by the state, they are considered authoritative and accurate by teachers and learners who are willing users thereof. The subliminal message projected through discourse marginalization in the selected textbooks is that women are only deserving of second-place status.

However, although the textbooks have these biased representations, teachers and learners need not remain trapped in them; they can use them as a tool to generate alternate thinking. Merely changing the representation of male to female is not going to solve the problem of gender bias in society; it might require discursive practices well beyond technical cleansing. The intention of the textbook writers may not be malicious nor to deliberately subjugate women yet, it happens in a way that is implicit. Critical teacher education is needed to rupture these hidden biases. There might also be a need for textbook writers to deconstruct their own ideological assumptions of gender.

In light of the results of this research, several recommendations are presented. Firstly, the need to perceive equality concepts between females and males in all roles and aspects in school textbook contents in reflecting life reconstruction about two genders and prevail over traditions and customs. Secondly, supervising school curriculum and school textbooks authors for awareness about gender equality through training courses. Thirdly, other lessons textbooks representation on gender equality should be studied in the future research.

\subsection{Acknowledgement}

The authors would like to express their appreciation for the support of the sponsors with Institute of Research and Community Services (LPMM) Universitas Brawijaya for Hibah Penelitian Pemula Project Number 696.48/UN10.C10/PN/2019.

\section{References}

[1] P. R. Indonesia, "Instruksi Presiden No. 9 Tahun 2000 Tentang Pengarusutamaan Gender Dalam Pembangunan Nasional," Jakarta Sekr. Negara Republik Indones., 2000.

[2] J. Taxel, "Children's literature: A researeh proposal from the perspettive of the soriology of school knowledge," S. Castell, A. Luke, C. Luke,. Lang. Auth. Crit., vol. 22, pp. 32-45, 1989.

[3] K. Crawford, "Inter-cultural education: The role of school textbook analysis in shaping a critical discourse on nation and society," in UK Pacific Circle Consortium 27th Annual Conference, Hong Kong, 2004, pp. 21-23.

[4] A. Hodkinson, "Inclusive Education and the cultural representation of disability and Disabled people within the English Education System: a critical examination of the mediating influence of primary school textbooks," IARTEM e-Journal, vol. 1, no. 1, pp. 1-19, 2007.

[5] J. F. K. Lee, "A hidden curriculum in Japanese EFL textbooks: Gender representation," Linguist. Educ., vol. 27, pp. 39-53, 2014.

[6] P. Chung, "Textbooks and genders: gender representation in teaching materials of liberal studies in Hong Kong," 2014. 
[7] I. Kizllaslan, "Student teachers' perceptions of gendered texts in English language textbooks," Procedia-Social Behav. Sci., vol. 2, no. 2, pp. 3528-3531, 2010.

[8] S. Al-Qatawneh and A. Al Rawashdeh, "Gender representation in the Arabic language textbook for the ninth grade approved by the Ministry of Education for use in schools in the United Arab Emirates (UAE)," Stud. Educ. Eval., vol. 60, pp. 90-98, 2019.

[9] A. G. J. N. Nasution, "Bias Gender dalam Buku Pelajaran SKI Tingkat Madrasah Ibtidaiyah," $J$. Contemp. Islam Muslim Soc., vol. 1, no. 2, pp. 248-276, 2017.

[10] S. SAKBANI, "Analisis Ketidakadilan Gender dalam Buku Pendidikan Agama dan Budi Pekerti (Studi Komparasi Buku Pendidikan Agama Islam dan Kristen kelas XI Tingkat SMA).” IAIN Salatiga, 2018.

[11] A. H. Mawadah, "Nilai Kesetaraan Gender pada Cerpen dalam Buku Teks Bahasa Indonesia SMA," LITERA, vol. 17, no. 1, 2018.

[12] M. Amini, "Bias Gender dalam Historiografi Indonesia dan Penulisan Sejarah Perempuan,” $J$. Peremp. 23, vol. 3, 2019.

[13] J. F. K. Lee, "Gender representation in Hong Kong primary school ELT textbooks-a comparative study," Gend. Educ., vol. 26, no. 4, pp. 356-376, 2014.

[14] D. A. Stockdale, "Gender representation in an EFL textbook," Master's thesis, Univ. Birmingham, UK. Retrieved from http//www. cels. bham. ac. uk/resources/essays/DAStockdaleSociolinguistics. pdf, 2006.

[15] S. M. Maistry and P. Pillay, "Gender representation in contemporary Grade 10 Business Studies textbooks in South Africa," Perspect. Educ., vol. 32, no. 4, pp. 74-92, 2014.

[16] J. Sunderland, Exploring gender: Questions and implications for English language education. Prentice Hall International, 1994.

[17] K. Opoku-Amankwa, "What happens to textbooks in the classroom? Pupils' access to literacy in an urban primary school in Ghana," Pedagog. Cult. Soc., vol. 18, no. 2, pp. 159-172, 2010. 